\title{
ANALISIS PENGARUH KEPUASAN PERGANTIAN METODE PERSEDIAAN BARANG DENGAN PEMAKAIAN METODE ABC DALAM MENINGKATKAN KUALITAS PRODUK (STUDI KASUS. UD. RIZKY ASSILA ULFA)
}

\author{
Yahya Tanjung \\ Fakultas Ekonomi dan Bisnis, \\ Program Studi Manajemen, Universitas Potensi Utama, \\ Jl. K.L.Yos Sudarso, Tj. Mulia, Medan Deli, Kota Medan-20241 Telp: (061) 6640525, \\ e-mail: tanjungyahya67@gmail.com
}

\begin{abstract}
ABSTRAK
Tujuan penelitian ini dilaksanakan untuk mengganti dan menerapkan metode persediaan barang bersifat tradisional menjadi metode ABC (Activity Based Costing). Metode ABC banyak diterapkan di perusahaan dunia. Dimana, metode $A B C$ mengurangi distorsi harga yang disebabkan oleh penentuan harga yang masih dilakukan secara tradisional, sehingga harga produk yang dikeluarkan bisa akurat bukan hanya asal -asalan. Metode ini juga digunakan untuk mengendalikan sejumlah kecil barang, tetapi mempunyai nilai investasi yang tinggi. Analisis ABC ini menggolongkan barang berdasarkan peringkat nilai dari nilai tertinggi hingga terendah dan kemudian dibagi menjadi kelas-kelas besar terprioritas sesuai dengan jenis dan fungsi masing-masing barang. Setelah terjadi pergantian dan penerapan metode persediaan barang dengan menggunakan metode ABC (Activity Based Costing) maka akan dianalisis lebih lanjut tentang faktor kepuasan dalam penggunaan metode ABC (Activity Based Costing). Faktor kepuasan dalam hal ini terdiri dari Tanggung jawab, kinerja karyawan dan kualitas produk
\end{abstract}

Kata kunci : Tanggung Jawab, Kinerja Karyawan, Kualitas Produk, Kepuasan Pemakaian Metode ABC

\section{ABSTRACT}

The purpose of this study was to replace and apply the traditional inventory method to the ABC (Activity Based Costing) method. The ABC method is widely applied in world companies. Where, the ABC method reduces price distortions caused by traditional pricing, so that the price of the product issued can be accurate, not just carelessly. This method is also used to control a small number of goods, but has a high investment value. This ABC analysis classifies goods based on value ratings from the highest to the lowest value and then is divided into major priority classes according to the type and function of each item. After the change and application of the inventory method using the ABC (Activity Based Costing) method, it will be analyzed further about the satisfaction factor in the use of the $A B C$ (Activity Based Costing) method. The satisfaction factor in this case consists of responsibility, employee performance and product quality

Keywords: Responsibility, Employee Performance, Product Quality, Satisfaction Using the ABC Method 


\section{Latar Belakang}

\section{PENDAHULUAN}

Metode ialah suatu cara yang sistematis yang dimanfaatkan untuk mencapai tujuan tertentu dengan efisiensi, biasanya dilakukan dengan urutan tahapan- tahapan yang teratur. Biasanya metode sangat diperlukan dalam bidang produksi, persediaan barang hingga bidang pemasarannya, tanpa suatu metode maka usaha tersebut tidak dapat berjalan dengan optimal atau berantakan dan tidak jelas arah tujuan yang akan dicapai. Oleh sebab seperti itu, metode memiliki peranan penting dalam mendukung suatu usaha guna mengoptimalkan laba perusahaan.[1] Dengan kata lain, metode merupakan suatu prosedur yang berurutan secara tepat dari tahapan- tahapan instruksi yang menerangkan apa( what) yang harus dikerjakan, siapa( who) yang mengerjakan, kapan( when) dikerjakan dan bagaimana( how) mengerjakannya.[2]

Salah satu perusahaan yang telah menerapkan suatu metode persediaan barang dalam produk usahanya ialah UD. Rizky Assila Ulfa. UD. Rizky Assila Ulfa ini bergerak dibidang produksi bangunan seperti paving blok taman, batu bata, pagar beton dan pembatas jalan. Dimana, UD. Rizki Assila Ulfa sangat memprioritaskan kepuasan konsumen dengan menampilkan kualitas produk yang terbaik. Namun, UD. Rizky Assila Ulfa masih menerapkan metode persediaan barang yang bersifat tradisional, sehingga sering melakukan kesalahan dalam menentukan harga keuntungan yang didapat tidak sesuai dengan biaya produksi yang dikeluarkan. Hal itu dikarenakan tidak mendapatkan informasi yang lengkap tentang semua biaya- biaya yang harus dikeluarkan dalam proses produksi suatu produk secara akurat, sehingga barang yang dipasok banyak yang terbuang sia- sia. Hal ini mengakibatkan secara berangsur- angsur akan mengalami kerugian.[3]

Penelitian ini bertujuan untuk mengganti dan menerapkan menerapkan metode persediaan barang bersifat metode $\mathrm{ABC}($ activity based costing). Metode ini juga digunakan untuk mengendalikan sejumlah kecil barang, tetapi mempunyai nilai investasi yang tinggi. Analisis ABC ini menggolongkan barang berdasarkan peringkat nilai dari nilai tertinggi hingga terendah dan kemudian dibagi menjadi kelas- kelas besar terprioritas sesuai dengan jenis dan guna masingmasing barang. Berdasarkan hal ini, maka dalam penelitian ini dibuat sebuah dokumen mengenai penerapan metode ABC dalam meningkatkan kualitas produk( Studi Kasus UD. Rizky Assila Ulfa) yang merujuk pada faktor kepuasan yang mempengaruhi pengambilan keputusan dalam pemakaian metode $\mathrm{ABC}$ meliputi tanggung jawab, kinerja karyawan, dan kualitas produk. Dari hal ini, perusahaan harus lebih memperhatikan struktur modal agar dapat berkembang dan bertahan di tengah berkembangnya pertumbuhan ekonomi. Besarnya pertumbuhan ekonomi ini menjadi stimulus berbagai perusahaan khususnya yang ada di Indonesia dalam mengembangkan usahanya salah satunya Perusahaan Pertambabngan sektor batu bara. Perusahaan sektor batu bara ini merupakan perusahaan yang memiliki saham yang cukup kapabilitas pasar yang tinggi.

\section{Tujuan Penelitian}

Adapun tujuan penelitian yang ingin dicapai penulis adalah:

1. Metode $\mathrm{ABC}$ ( activity based costing) yang diterapkan dapat memberikan solusi atas persediaan barang produksi yang dihasilkan sehingga mengendalikan sejumlah kecil barang, tetapi mempunyai nilai investasi yang tinggi.

2. Untuk mengetahui pengaruh dan elastisitas variabel tanggung jawab, kinerja karyawan dan kualitas produk terhadap metode $\mathrm{ABC}$.

3. Penelitian ini diharapkan dapat memberikan maanfaat dari sisi keilmuan yaitu memberikan pengetahuan mengenai metode $\mathrm{ABC}$ sebagai solusi terbaik dalam mengendalikan persediaan barang. 


\section{LANDASAN TEORI}

Persediaan adalah bahan baku atau barang yang disimpan yang akan digunakan untuk memenuhi tujuan tertentu misalnya untuk digunakan dalam proses produksi atau perakitan, untuk dijual kembali atau untuk suku cadang dari peralatan atau mesin. Persediaan dapat berupa bahan mentah, bahan pembantu, barang dalam proses, barang jadi ataupun suku cadang.[4]. Persediaan merupakan salah satu aset penting dalam perusahaan karena biasanya mempunyai pengaruh terhadap besar kecilnya biaya operasi, perencanaan dan pengendalian persediaan merupakan salah satu kegiatan penting untuk mendapatkan perhatian khusus dari manajemen perusahaan.

Persediaan pada perusahaan manufaktur menunjuk pada item- item yang menjadi bagian dari produk akhir perusahaan. Persediaan dalam manufaktur diklasifikasikan menjadi persediaan bahan baku( raw materials), produk jadi( finished products), komponen( component parts), bahan penolong( supplies) dan barang dalam proses( work in process). Pada perusahaan jasa, inventori menunjuk pada barang- barang tangible yang dijual dan bahan penolong yang diperlukan untuk menyajikan jasa. Dalam kebanyakan text book, pembahasan inventori senantiasa difokuskan pada persediaan bahan baku di perusahaan manufaktur.

\section{Pendekatan Penelitian}

Pendekatan penelitian ini adalah deskriptif kuantitatif, bertujuan untuk menjelaskan fenomena yang ada dengan menggunakan angka- angka dalam menggambarkan karakteristik individu atau kelompok. Adapun pendekatan kuantitatifnya lebih menekankan pada pengujian teori- teori atau hipotesis- hipotesis melalui pengukuran variabel- variabel penelitian dalam angka( quantitative) dan melakukan analisis data dengan prosedur statis dan permodelan sistematis. Sedangkan metode deskriptifnya lebih menekankan pada pencarian fakta dengan interprestasi yang tepat. Penelitian ini lebih mengutamakan pada pencarian hubungan antara dua variabel atau lebih.

\section{Populasi dan Sampel}

Populasi adalah keseluruhan jumlah yang terdiri atas obyek atau subyek yang mempunyai karakteristik dan mutu tertentu yang ditetapkan oleh peneliti untuk diteliti dan kemudian ditarik kesimpulanya. Populasi dalam penelitian ini adalah karyawan UD. Rizky Assila Ulfa yaitu berjumlah 50 orang. Sementara itu, sampel adalah bagian dari populasi( contoh), untuk dijadikan sebagai bahan penelaahan dengan harapan contoh yang diambil dari populasi tersebut dapat diwakili( representative) terhadap populasinya. Sampel dalam penelitian ini adalah seluruh karyawan UD. Rizky Assila Ulfa yaitu berjumlah 50 orang. Metode pemilihan sampel yang digunakan adalah purposive sampling yaitu metode pengambilan sampel berdasarkan tujuan penelitiannya. Berdasarkan metode tersebut maka sampel dari penelitian ini berupa data yang diperoleh dari karyawan UD. Rizky Assila Ulfa yaitu berjumlah 50 orang.

\section{Sumber Data}

Sumber data yang diperlukan dalam penelitian ini adalah data primer dan data sekunder. Data primer adalah data yang dikumpulkan dari responden karyawan UD. Rizky Assila Ulfa melalui hasil pengisian kuesioner yang kemudian diolah langsung oleh peneliti. Sedangkan data sekunder adalah data yang diperoleh dari pihak tertentu yang telah dikumpulkan oleh peneliti, data ini diperoleh dengan cara pencatatan dilapangan berupa laporan-laporan yang mendukung penelitian ini. Dengan demikian, data yang digunakan dalam penelitian ini bersifat cross section. cross section yaitu data yang memiliki objek yang banyak pada tahun yang sama atau data yang dikumpulkan dalam satu waktu terhadap banyak objek.[19] Dan penelitian ini juga menggunakan studi kepustakaan yang berkaitan dengan objek penelitian guna mendukung hasil penelitian ini. 


\section{Teknik Analisis Data}

Teknik analisis data yang digunakan dalam penelitian ini ialah teknik analisis regresi linier berganda. Teknik analisis regresi linier berganda ialah persamaan garis lurus (regresi linier) untuk memprediksi variabel dependent (numerik) dari beberapa variabel independent (numerik atau kategorik). Metode ini digunakan untuk meramalkan pengaruh dua variabel prediktor atau lebih terhadap satu variabel kriterium atau untuk membuktikan ada atau tidaknya hubungan fungsional antara variabel bebas (X) yaitu tanggung jawab (X1), kinerja karyawan (X2), dan kualitas produk (X3) dengan sebuah variabel terikat (Y) yaitu metode ABC.[21]

Data yang diperoleh kemudian di anaslisis dengan analisis regresi linier berganda dengan menggunakan program spss versi 19. Spss (Statistical Package for The Social Science) merupakan perangkat lunak yang disediakan untuk komputasi ekonometrik dan digunakan dalam analisis ekonometrik, peramalan dan simulasi dengan menggunakan Graphical User Interface (GUI) yang user-friendly, berbasis sistem operasi Windows Setelah data dianalisis menggunakan spss, kemudian hasil tersebut di jelaskan secara deskriptif.

Keunggulan dari Analisis regresi linier berganda ini ialah dapat meningkatkan keakuratan hubungan variabel terikat dengan variabel bebas.[22] Dengan demikian, untuk menguji hipotesis dalam penelitian ini, maka akan digunakan model persamaan regresi sebagai berikut:

$$
\text { K.P.Metode } A B C=a+b 1 T J+b 2 K K+b 3 K P+e
$$

Dimana:

$\begin{array}{ll}\text { K.PMetode ABC } & =\text { Kepuasan Pemakaian Metode activity based costing } \\ \text { TJ } & =\text { Tanggung Jawab } \\ \text { KK } & =\text { Kinerja karyawan } \\ \text { KP } & =\text { Kualitas Produk } \\ \text { a } & =\text { Konstanta } \\ \text { b1,b2,...b3 } & =\text { Koefisien regresi } \\ \text { e } & =\text { Error term }\end{array}$

\section{Uji Validitas dan Reliabilitas}

Uji validitas adalah uji yang digunakan untuk mengetahui kelayakan butir-butir dalam suatu daftar pertanyaan dalam mendefinisikan suatu variabel. Daftar pertanyaan ini pada umumnya mendukung suatu kelompok variabel tertentu. Uji validitas sebaiknya dilakukan pada setiap butir pertanyaan di uji validitasnya. Hasil $r$ hitung kita bandingkan dengan $r$ tabel dimana $\mathrm{df}=\mathrm{n}-2$ dengan sig 5\%. Jika $r$ tabel $<$ r hitung maka valid.

\section{Uji Asumsi Klasik}

Uji Asumsi Klasik ini digunakan untuk mengetahui kondisi data yang digunakan dalam penelitian. Hal ini dilakukan agar diperoleh model analisis yang tepat. Model analisis regresi linier berganda penelitian ini mensyaratkan uji asumsi klasik terhadap data yang meliputi uji normalitas, uji multikolinieritas dan uji heterokedastisitas. 


\section{Uji Normalitas}

Uji normalitas digunakan untuk mengetahui apakah dalam model regresi variabel pengganggu atau residual memiliki distribusi normal. Model regresi yang baik harus memiliki data normal atau mendekati normal. Untuk menentukan data terdistribusi normal atau tidaknya, maka digunakan uji Jargue-Berra test atau J-B test dengan ketentuan jika probabilitas lebih besar dari 0,05 ( Jika Sig > 0,05) maka data terdistibusi normal dan tidak terkendala dalam masalah normalitas, namun jika probabilitas lebih kecil dari 0,05 (Jika Sig $<0,05$ ) maka data tidak terdistribusi normal. berikut:

Adapun pengujian normalitas dengan uji Jarque-Berra test menggunakan formulasi sebagai

$$
\mathrm{JB}=\mathrm{n} S 2 \underline{+k-3} 2
$$

$6 \quad 24$

Dimana s menunjukkan skewness dan k menunjukkan kurtosis

Pada suatu distribusi normal, nilai skewness sama dengan nol dan nilai kurtosis sama dengan 3. Distribusi kesalahan penganggu kemungkinan berasal dari distribusi normal jika nilai JB lebih kecil daripada nilai $\mathrm{x} 2$ dengan $\alpha$ tertentu dan dengan $\mathrm{df}=2$.

\section{Uji Multikolinieritas}

Uji multikolinieritas adalah kondisi adanya hubungan linier antarvariabel, dimana antarvariabel independent yang terdapat dalam model memiliki hubungan yang sempurna atau mendekati sempurna (koefisien korelasinya tinggi atau bahkan mendekati 1). Uji multikolinieritas diperlukan untuk mengetahui ada tidaknya akibat korelasi antar variabel independent dalam satu model. Model korelasi yang baik seharusnya tidak terjadi korelasi diantara sesama variabel independent.

Untuk mendeteksi ada atau tidaknya multikolinieritas di dalam model regresi ini sebagai berikut:

1.Membandingkan hasil estimasi R2 dengan $\mathrm{r} 2$ parsial masing-masing variabel. Apabila R2 lebih besar daripada r2 masing-masing variabel, maka hasil estimasi model regresi dinyatakan bebas dari multikolinearitas.

2.Menganalisis matriks korelasi variabel-variabel independen. Jika antar variabel independen terjadi korelasi yang cukup tinggi (umumnya > 0,90), maka indikasi terjadi multikolinearitas. Tidak adanya nilai korelasi yang tinggi antar variabel independen tidak berarti bebas dan multikolinieritas. Multikolinieritas dapat terjadi karena kombinasi dua atau lebih variabel independen.

3.Multikolinieritas dapat dilihat dari nilai tolerance dengan rumus $(\mathrm{Tol}=1 / \mathrm{VIF}=1-\mathrm{R} 2)$ dan lawannya yaitu variance inflactor factor (VIF) dengan rumus (VIF =1/1-r2). Kedua variabel ini menunjukkan setiap variabel independen manakah yang dijelaskan oleh variabel independen lainnya. Tolerance mengukur variabilitas variabel independen yang terpilih yang tidak dijelaskan oleh variabel independen lainnya. Jadi nilai tolerance yang rendah sama dengan VIF yang tinggi. Batasan umum yang digunakan untuk mengukur multikolinieritas adalah tolerance $<0,1$ dan nilai VIF > 10 maka terjadi multikolinieritas. 


\section{Uji Heterokedastisitas}

Heteroskedastisitas adalah varian residual yang tidak sama pada semua pengamatan didalam model regresi. Regresi yang baik seharusnya tidak terjadi heteroskedastisitas. Cara memprediksi ada tidaknya heterokedastisitas pada suatu model dapat dilihat dengan pola gambar Scatterplot, regresi yang tidak terjadi heterokedastisitas jika:

a.Titik-titik data menyebar di atas dan di bawah atau disekitar angka 0

b.Titik-titik data tidak mengumpul hanya di atas atau di bawah saja

c.Penyebaran titik-titik data tidak boleh membentuk pola bergelombang melebar kemudian menyempit dan melebar kembali

d.Penyebaran titik-itik data tidak berpola.

Selain pemakaian scatterplot dalam pengujian heterokedastisitas diatas, maka dapat dilakukan juga uji Heterokedatisitas dengan pemakaian uji Glejser. Uji Glejser ini mengusulkan untuk meregres nilai absolute residual terhadap variabel bebas, dengan persamaan sebagai berikut:

$\mathrm{Ut}=\alpha+\beta \mathrm{Xt}+\mathrm{vi}$

\section{METODOLOGI PENELITIAN}

\section{METODE ABC}

Metode ABC (Activity Based Costing) adalah pendekatan penghitungan analisis biaya yang membantu manajemen untuk menganalisis dasar perhitungan biaya secara lebih bermanfaat, menginformasikan aktivtas seluruh bagian organisasi yang memberikan gambaran lebih jelas terhadap hubungan antara aktivitas dan biaya, selain itu, ABC merupakan dasar upaya untuk memahami pola perilaku seluruh jenis biaya organisasi yang menghubungkan biaya operasi dalam sebuah rantai nilai agar manajemen mampu mengidentifikasi faktor-faktor yang mendorong terjadinya pengeluaran serta memfokuskan diri pada jenis biaya kunci dan selanjutnyamengelola biaya tersebut secara lebih efektif. Berikut ini merupakan data yang diambil dari UD. Rizky Assila Ulfa dalam pemakaian metode persediaan barang yang bersifat metode ABC (Activity Based Costing).

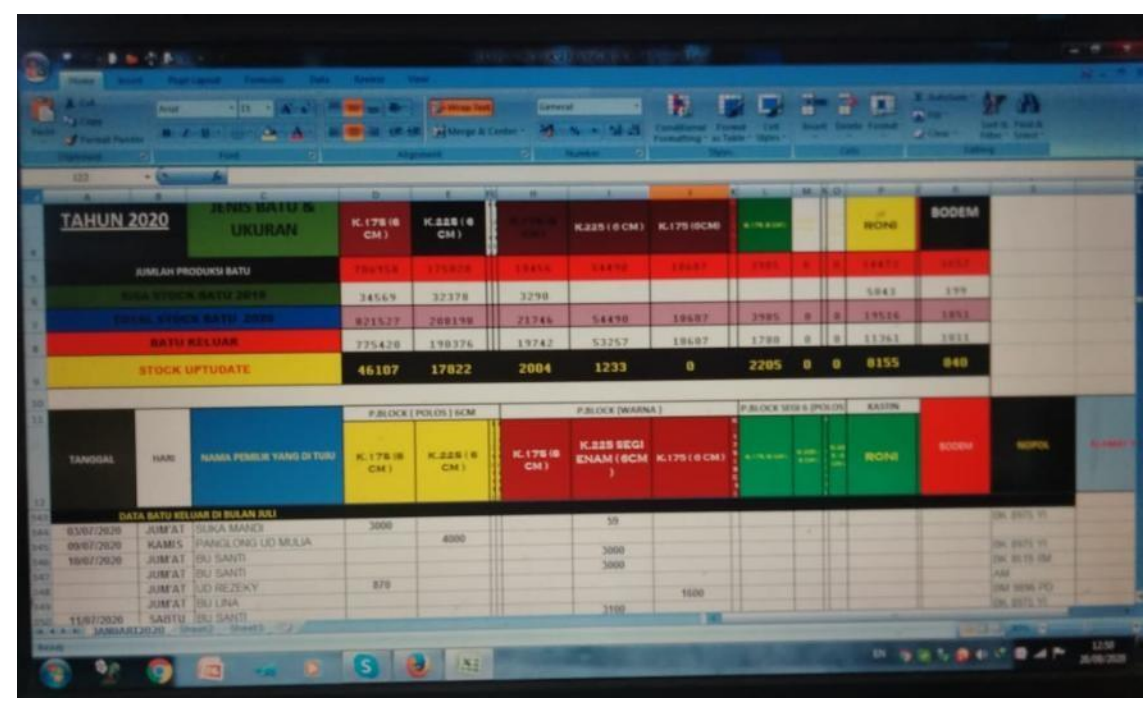

Gambar C.2 Pencatatan Data Dengan Menerapkan Metode ABC 
Dari gambar diatas terlihat bahwa, pencatatan dilakukan dengan sistem komputer dengan pemakaian Microsoft Excel namun sudah menggunakan sistem dengan lebih baik dan sesuai dengan warna sehingga terlihat bahwa metode $\mathrm{ABC}$ sudah diterapkan seperti warna kuning diterapkan untuk kode yang yaitu paving blok polos K- 175 dan K-225, namun di bagian atasnya dibedakan dengan warna K-175 berwarna cokelat sedangkan K-225 berwana hitam, hal ini dikarenakan bahan yang digunakan berbeda dan K-225 lebih mahal harganya dari K-175 yaitu K175 seharga Rp. 1.100/buah sedangkan K 225 seharga Rp.2000/buah, selain itu, paving blok warna K-175 dan K-225 di beri warna merah, paving blok segi enam diberi warna hijau, alamat rumah konsumen diberi warna biru dan lainny. Selain itu, hasil barang produksi juga dibedakan penempatan barangnya berdasarkan bahan yang digunakan dalam memproduksi paving blok tersebut. Metode ABC sangat memberikan manfaat yang besar untuk perusahaan dagang UD. Rizky Assila Ulfa, karena dengan adanya metode ini, maka mengurangi distorsi harga yang disebabkan oleh penentuan harga yang masih dilakukan secara tradisional, sehingga harga produk yang dikeluarkan bisa akurat bukan hanya asal - asalan. Metode ini juga digunakan untuk mengendalikan sejumlah kecil barang, tetapi mempunyai nilai investasi yang tinggi. Analisis ABC ini menggolongkan barang berdasarkan peringkat nilai dari nilai tertinggi hingga terendah dan kemudian dibagi menjadi kelas-kelas besar terprioritas sesuai dengan jenis dan fungsi masingmasing barang.

\section{HASIL PENELITIAN}

Kepuasan pemakaian metode $\mathrm{ABC}$ (activity based costing) merupakan suatu perasaan positif tentang pekerjaan seseorang yang merupakan hasil dari sebuah evaluasi karakteristiknya. Seseorang dengan tingkat kepuasan yang tinggi memiliki perasaan positif tentang pekerjaan tersebut, sedangkan seseorang yang tidak puas memiliki perasaan negatif tentang pekerjaan tersebut. Berikut ini merupakan data dari tingkat persentase kepuasan dalam pemakaian metode ABC (activity based costing) dari 50 responden karyawan di UD. Rizky Assila Ulfa:

\section{Tabel 1. Hasil Kepuasan Pemakaian metode ABC (Activity Based Costing) 50 Karyawan UD. Rizky Assila Ulfa}

\begin{tabular}{|l|l|l|c|c|}
\hline No & $\begin{array}{c}\text { Dimensi Kepuasan Pemakaian metode } \\
\text { ABC (activity based costing) }\end{array}$ & Kategori & Jumlah & \% \\
\hline \multirow{2}{*}{1} & Tanggung Jawab & Puas & 46 & $92 \%$ \\
& & Tidak puas & 4 & $8 \%$ \\
\hline \multirow{2}{*}{2} & \multirow{2}{*}{ Kinerja Karyawan } & Puas & 48 & $96 \%$ \\
& & Tidak puas & 2 & $4 \%$ \\
\hline \multirow{2}{*}{3} & Kualitas Produk & Puas & 47 & $94 \%$ \\
& & Tidak puas & 3 & $6 \%$ \\
\hline \multirow{2}{*}{ Rata-Rata Tingkat Kepuasan } & Puas & $\mathbf{4 7}$ & $\mathbf{9 4 \%}$ \\
& \multirow{2}{*}{ Ridak puas } & $\mathbf{3}$ & $\mathbf{6 \%}$ \\
\hline
\end{tabular}

Dari tabel diatas, maka dapat disimpulkan bahwa rata-rata tingkat kepuasan yang didapat dari karyawan UD. Rizky Assila Ulfa dalam pemakaian metode ABC (activity based costing) sebesar $94 \%$, sementara sisanya $6 \%$ tidak puas dengan pemakaian metode $\mathrm{ABC}$.

\section{Uji Validitas dan Reliabilitas}

Uji Validitas digunakan untuk melihat kelayakan butir-butir dalam suatu daftar pertanyaan yang untuk mendefinisikan suatu variabel yang digunakan dalam penelitian. Hasil $r$ hitung kita 
bandingkan dengan $\mathrm{r}$ tabel dimana $\mathrm{df}=\mathrm{n}-2$ dengan sig 5\%. Jika $\mathrm{r}$ tabel $<\mathrm{r}$ hitung maka valid. Sedangkan, Uji reliabilitas adalah ukuran suatu kestabilan dan konsistensi responden dalam menjawab hal yang berkaitan dengan kontruk-kontruk pertanyaan merupakan dimensi suatu variabel dan disusun dalam suatu bentuk kuesioner. Uji reliabilitas dapat dilakukan secara bersamasama terhadap seluruh butir pertanyaan. Jika nilai Alpha >0,60 maka reliabel. Variabel dependent dalam penelitian ini adalah Kepuasan Pemakaian Metode ABC (Activity Based Costing), sedangkan variabel independent dalam penelitian ini adalah tanggung jawab, kinerja karyawan, dan kualitas produk.

\section{Variabel Dependen}

Variabel terikat (dependent variable) ialah variabel atau data yang dipengaruhi. Dalam penelitian ini variabel terikat (Y) hanya terdiri dari satu variabel saja yaitu Kepuasan Pemakaian Metode ABC (Activity Based Costing).

Tabel 2. Item-Total Statistics

\begin{tabular}{|l|r|r|r|r|}
\hline & $\begin{array}{c}\text { Scale Mean if } \\
\text { Item Deleted }\end{array}$ & $\begin{array}{c}\text { Scale Variance if } \\
\text { Item Deleted }\end{array}$ & $\begin{array}{c}\text { Corrected } \\
\text { Item-Total } \\
\text { Correlation }\end{array}$ & $\begin{array}{c}\text { Cronbach's Alpha if } \\
\text { Item Deleted }\end{array}$ \\
\hline Soal_1 & 13.02 & 7.408 & .693 & .849 \\
Soal_2 & 12.98 & 7.204 & .753 & .834 \\
Soal_3 & 12.86 & 7.266 & .801 & .824 \\
Soal_4 & 12.72 & 7.553 & .674 & .854 \\
Soal_5 & 12.74 & 7.870 & .596 & .872 \\
& & & & \\
\hline
\end{tabular}

Kepuasan pemakaian metode ABC (Activity Based Costing) (Y) adalah suatu perasaan positif tentang pekerjaan seseorang yang merupakan hasil dari sebuah evaluasi karakteristiknya dalam pemakaian metode ABC. Berikut ini adalah data uji validitas dari data kepuasan pemakaian metode $\mathrm{ABC}$ yang didapatkan pada 50 responden di UD. Rizky Assila Ulfa.

Dengan penggunaan jumlah responden sebanyak 50, maka $r$ tabel yang diperoleh melalui tabel $r$ product moment pearson dengan df (degree of freedom) $=n-2$ dalam sig 5\%, jadi $50-2=48$, maka $r$ tabel $=0,238$. Butir pertanyaan dikatakan valid, jika nilai $r$ hitung $>r$ tabel. Hal ini dapat dilihat dari Corrected Item Total Correlation, analisis outputnya sebagai berikut:

Tabel 3. Uji Validitas Kepuasan Pemakaian Metode ABC

\begin{tabular}{|c|c|c|c|}
\hline Variabel & r Hitung & r Tabel & Keterangan \\
\hline Pertanyaan 1 & 0,693 & 0,238 & Valid \\
\hline Pertanyaan 2 & 0,753 & 0,238 & Valid \\
\hline Pertanyaan 3 & 0,801 & 0,238 & Valid \\
\hline Pertanyaan 4 & 0,674 & 0,238 & Valid \\
\hline Pertanyaan 5 & 0,596 & 0,238 & Valid \\
\hline
\end{tabular}


Sedangkan uji reliabilitasnya dapat dilihat dari cronbach's alpha, jika nilai Alpa

$>0,60$ maka kontruk pertanyaan yang merupakan dimensi variabel adalah reliabel. Maka hasil outputnya yang dihasilkan yaitu:

Tabel 4. Reliability Statistics

\begin{tabular}{|r|l|}
\hline Cronbach's Alpha & N of Items \\
& \\
\hline .874 & 5 \\
\hline
\end{tabular}

Dari data yang telah disajikan diatas terlihat bahwa nilai cronbach's alpha sebesar 0,835 > 0,60 , maka dimensi variabel tanggung jawab adalah reliabel.

\section{Analisis Data}

Analisis data adalah sebuah proses untuk memeriksa, membersihkan, mengubah dan membuat pemodelan data dengan maksud untuk menemukan informasi yang bermanfaat sehingga dapat memberikan petunjuk bagi peneliti untuk mengambil keputusan terhadap pertanyaanpertanyaan penelitian. Analisis data memilki rancangan analisis data. Rancangan analisis data adalah bagian integral dari proses penelitian yang dituangkan baik dalam bentuk tulisan atau tidak. Adapun rancangan analisis data dalam penelitian ini dapat dilihat dari persamaan rumusan regresi linier berrganda di bawah ini.

$$
\text { K.P.Metode } \mathrm{ABC}=\mathrm{a}+\mathrm{b} 1 \mathrm{TJ}+\mathrm{b} 2 \mathrm{KK}+\mathrm{b} 3 \mathrm{KP}+\mathrm{e}
$$

Dari persamaan regresi di atas, maka dapat di analisis dengan menggunakan analisis regresi linier berganda. Analisis regresi linier berganda dilakukan untuk menguji pengaruh antara variabel satu dengan variabel lain. Dimana, analisis ini mempergunakan program SPSS Versi 19. Sebelum di analisis dilakukan uji asumsi klasik. Berikut uji model dari persamaan regresi di atas.

\section{Pembahasan}

Hipotesis yang diajukan dalam penelitian ini adalah "Terdapat pengaruh tanggung jawab, kinerja karyawan dan kualitas produk terhadap kepuasan pemakaian metode ABC. Berdasarkan hasil penelitian yang diperoleh bahwa tanggung jawab, kinerja karyawan dan kualitas produk secara simultan berpengaruh terhadap kepuasan pemakaian Metode ABC.

Kualitas produk dalam kepuasan pemakaian metode $\mathrm{ABC}$ mengacu pada kemampuan suatu perusahaan untuk memberikan identitas atau ciri pada setiap produknya sehingga konsumen dapat mengenali produksi tersebut. Hasil penelitian ini menunjukkan bahwa kualitas barang produksi berpengaruh positif tapi tidak signifikan, yang berarti jika kualitas produk meningkat maka tidak mempengaruhi peningkatan pada kepuasan pemakaian metode ABC. Hal ini mungkin dikarenakan daya tahan suatu produk menunjukkan usia produk, yaitu jumlah pemakaian suatu produk sebelum produk itu digantikan atau rusak dan karakteristik atau ciri-ciri tambahan yang melengkapi manfaat dasar suatu produk.

Hal ini sesuai dengan teori yang dikemukakan oleh Glenn A. Welsch bahwa jika kualitas produk naik maka kepuasan metode $\mathrm{ABC}$ tidak mengalami peningkatan yang berarti metode $\mathrm{ABC}$ dapat mengurangi pemborosan barang rusak dan barang cacat dengan mendeteksi kesalahan pada sumbernya dan mengurangi waktu tunggu (lead time) karena ukuran lot yang kecil sehingga sel produksi lebih dapat memberikan umpan balik terhadap masalah mutu. 


\section{KESIMPULAN}

Berdasarkan hasil analisis data yang telah dikemukakan sebelumnya, maka dapat ditarik kesimpulan bahwa:

1. Rata-rata tingkat kepuasan yang didapat dari karyawan UD. Rizky Assila Ulfa dalam pemakaian metode $\mathrm{ABC} 94 \%$, sementara sisanya $6 \%$ tidak puas dengan pemakaian metode $\mathrm{ABC}$

2. Hasil analisis regresi linier berganda menunjukkan bawa secara simultan variabel tanggung jawab, kinerja karyawan dan kualitas produk berpengaruh terhadap kepuasan pemakaian metode ABC dengan taraf kepercayaan 95\%, terlihat dari bahwa sig adalah0.000 $<0,05$ maka Ho ditolak dan dapat dilihat dari $\mathrm{F}$ hitung $=121,633$ dan $\mathrm{F}$ tabel $=2,807$, jadi 121 , $633>2,807$ maka Ho ditolak

3. Variasi faktor oleh variabel independen tanggung jawab, kinerja karyawan dan kualitas produk secara bersama-sama mampu menerangkan pengaruh terhadap kepuasan pemakaian metode $\mathrm{ABC}$ sebesar $88,1 \%$. Sedangkan sisanya sebesar $11,9 \%$ dijelaskan oleh variabel lain yang tidak diteliti atau di luar model.

4. Elastisitas hubungan antara variabel independen dengan variabel dependen dapat dilihat sebagai berikut:

a. Elastisitas hubungan variabel tanggung jawab berpengaruh berpengaruh positif dan signifikan terhadap kepuasan pemakaian metode $\mathrm{ABC}$, pengaruhnya sebesar 0,285 artinya jika tanggung jawab naik 1 satuan maka kepuasan pemakaian metode $\mathrm{ABC}$ akan naik sebesar 0,285 dengan asumsi variabel lain konstan.

b. Elastisitas hubungan variabel kinerja karyawan berpengaruh berpengaruh positif dan signifikan terhadap kepuasan pemakaian metode $\mathrm{ABC}$, pengaruhnya sebesar 0,623 artinya jika tanggung jawab naik 1 satuan maka kepuasan pemakaian metode $\mathrm{ABC}$ akan naik sebesar 0,623 dengan asumsi variabel lain konstan.

c. Elastisitas hubungan kualitas produk memiliki pengaruh yang positif tapi tidak signifikan terhadap kepuasan pemakaian metode ABC, sehingga kenaikan sebesar 0,123 tidak mempengaruhi dengan asumsi variabel lain konstan.

Berdasarkan hasil analisis data yang telah dikemukakan sebelumnya, maka dapat diberikan saran, sebagai berikut:

1. Bagi UD. Rizky Assila Ulfa, penelitian ini dapat menjadi tolak ukur dalam pengambilan langkah keputusan terhadap pemakaian metode $\mathrm{ABC}$ dalam melihat persediaan barang maupun dalam kegiatan operasional lainnya.

2. Penelitian lebih lanjut dapat menggunakan metode lain yang dimungkinkan lebih baik dari analisis variabel yang digunakan dalam penelitian ini. Dengan begitu, penelitian ini diharapkan dapat memperoleh hasil penelitian yang lebih beragam dengan menambah beberapa variabel lainnya. Selain itu dapat dicari sektor mana saja yang sangat peka terhadap variabel kepuasan pemakaian metode ABC.

\section{DAFTAR PUSTAKA}

[1] Algifari, Analisis Regresi Teori, Kasus dan Solusi, Yogyakarta: BPFE, 2000.

[2] Arafah, Santi, and Erika Apulina Sembiring. "ANALISIS PENGARUH KEPUASAN DENGAN PEMAKAIAN METODE PERPEKTUAL TERHADAP PENGGUNAAN 
APLIKASI QUICKBOOKS ACCOUNTING SYSTEM (Studi Kasus UD. Rizky assila ULFA)." Bisei: Jurnal Bisnis dan Ekonomi Islam 3.2 (2018)

[3] ARAFAH, SANTI, and YAHYA TANJUNG. "ANALISIS FAKTOR DETERMINAN YANG MEMPENGARUHI PEMAKAIAN METODE JIT (STUDI KASUS UD. PUSAKA BAKTI)." Bisei: Jurnal Bisnis dan Ekonomi Islam 4.01 (2019).

[4] Darsono dan Ari Purwanti, Penganggaran Perusahaan, Jakarta: Mitra Wacana Media, 2010

[5] Herjanto, Eddy, Manajemen Operasi, Jakarta: Grafindo, 2015.

[6] Juwandi, Hendy Irawan, Kepuasan Pelayanan Jasa, Jakarta: Erlangga, 2004

[7] Imam Ghozali, Aplikasi Analisis Multivariate dengan Program SPSS, Semarang: BP UNDIP, 2005

[8] Kuncoro, Mudjarad, Metode Riset Untuk Bisnis dan Ekonomi, Jakarta: Erlangga, 2009

[9] Manengkey, Natasya. "Analisis Sistem Pengendalian Intern Persediaan Barang Dagang dan Penerapan Akuntansi Pada PT. Cahaya Mitra Alkes." Jurnal EMBA: Jurnal Riset Ekonomi, Manajemen, Bisnis dan Akuntansi 2.3 (2014)

[10] Makisurat, Aprilia, Jenny Morasa, and Inggriani Elim. "Penerapan Sistem Pengendalian Intern Untuk Persediaan Barang Dagangan Pada CV. Multi Media Persada Manado." Jurnal EMBA: Jurnal Riset Ekonomi, Manajemen, Bisnis dan Akuntansi 2.2 (2014).

[11] Martusa, Riki, Stephanus Ryan Darma, and Verani Carolina. "Peranan metode activity based costing dalam menentukan cost of goods manufactured." Maksi (2010).

[12] Puspitawati, Lilis dan Sri Dewi Anggadini, Sistem Informasi Akuntansi, Yogyakarta: Graha Ilmu, 2011

[13] Sambuaga, Reinhard S. "Evaluasi Akuntansi Persediaan pada PT. Sukses Era Niaga Manado." Jurnal EMBA: Jurnal Riset Ekonomi, Manajemen, Bisnis dan Akuntansi 1.4 (2013).

[14] Sampeallo, Yulius Gessong. "Analisis pengendalian persediaan pada UD Bintang Furniture Sangasanga." Jurnal eksis 8.1 (2012): 2032-2035

[15] Suratinoyo, Ayu W. "Penerapan Sistem ABC Untuk Penentuan Harga Pokok Produksi Pada Bangun Wenang Beverage." Jurnal EMBA: Jurnal Riset Ekonomi, Manajemen, Bisnis dan Akuntansi 1.3 (2013).

[16] Sujarweni, V. Wiratna, Kupas Tuntas Penelitian Akuntansi Dengan SPSS, Yogyakarta: Pustaka Baru Press, 2016

[17] Rotikan, Gloria Stefanie. "Penerapan Metode Activity Based Costing Dalam Penentuan Harga Pokok Produksi Pada PT. Tropica Cocoprima." Jurnal EMBA: Jurnal Riset Ekonomi, Manajemen, Bisnis dan Akuntansi 1.3 (2013).

[18] Tamodia, Widya. "Evaluasi penerapan sistem pengendalian intern untuk persediaan barang dagangan pada PT. Laris Manis Utama Cabang Manado." Jurnal EMBA: Jurnal Riset Ekonomi, Manajemen, Bisnis dan Akuntansi 1.3 (2013). 
[19] Usman, Husaini, dan Purnomo Setiady Akbar, Pengantar Statistika (Jakarta: PT. Bumi Aksara, 2011

[20] Utri, Dhania Anggarani, and Arifin SABENI. Analisis Penggunaan Metode Activity Based Costing Sebagai Alternatif Dalam Menentukan Tarif SPP SMP-SMA Pada YPI Nasima Semarang Tahun 2010. Diss. Universitas Diponegoro, 2011

[21] Winarno, Wing Wahyu, Analisis Ekonometrika dan Statistika dengan Eviews, Yogyakarta: Sekolah Tinggi Ilmu Manajemen YKPN, 2009.

[22] Yasril dan Heru Subaris Kasjono, Analisis Multivariant: Untuk Penelitian Kesehatan, Jogjakarta: Mitra Cendikia Press, 2009.

[23] Sukmadinata, S. N. Metode Penelitian. Bandung: PT Remaja Rosdakarya, 2005.

[24] Yamin, Sofyan, and Heri Kurniawan. "SPSS Complete: Teknik Analisis Statistik Terlengkap dengan Software SPSS." Jakarta: Salemba Infotek (2009). 